\title{
POST-INFLAMMATORY ECTOPIA OF THE MACULA RESULTING IN APPARENT HYPERTROPIA*
}

\author{
BY \\ WALLACE S. FOULDS \\ Moorfields, Westminster and Central Eye Hospital
}

ECTOPIA of the macula is a rare condition, having been recorded in the literature only eight times (although a few instances of the condition have also been noted in the foetal eye). Its apparent rarity is thought to justify the publication of a further case, in which a vertical displacement of the macula resulted from an attack of choroido-retinitis.

Ectopia of the macula may be produced by several mechanisms. The anomaly may be developmental and congenital, associated with other eye defects (coloboma of the choroid, coloboma of the disc, etc.). The earlier recorded cases were of this type (Pflüger, 1885; Bernhard, 1898; Lange, 1900; Krüger, 1913; Triebenstein, 1919). Some of these cases may, however, have been post-inflammatory.

A less common developmental type is that due to an alteration in the rate of growth of the posterior pole of the eye during the early postnatal period. Mann (1937) notes that there is normally a movement of the macula away from the optic disc in the newborn and that this process may be limited or exaggerated by environmental factors. A case of this type was recorded by Cohen and Weisberg (1950).

The third and probably commonest aetiological factor is traction on the retina by post-inflammatory fibrous bands which may result from either a pre-natal or post-natal inflammatory lesion, and unlike the developmental group the ectopia of the macula in these cases is usually unilateral.

Cases of this type have been described by Beselin (1924), Bielschowsky (1930; a bilateral case with fundus lesions like hereditary syphilis), Stein (1931; a unilateral case resulting from ignipuncture for detached retina), Friedman (1942; a unilateral case with a lesion near the macula, thought to be related to birth trauma), and Blaxter (1951; a unilateral case following choroido-retinitis). The present case also falls into this category. 


\section{Case Report}

A male infant aged 2 years was admitted to the Westminster Branch of Moorfields, Westminster and Central Eye Hospital, with an acute right hypopyon iritis which settled on treatment with mydriatics to leave a posterior synechia below and a very hazy vitreous through which no retinal detail could be seen. The aetiology of the condition remained obscure.

The Wassermann reaction was negative, chest $x$-ray normal, no radio-opaque foreign body in the orbit, Mantoux test negative, blood picture normal, no radiological evidence of abnormal intracranial calcification, serological tests for toxoplasmosis negative.

During the next 6 months the vitreous gradually cleared to reveal a healed focus of choroido-retinitis in the periphery of the fundus below and arising from this a band of fibrous tissue which ran upwards from the periphery to be inserted into the retina about one disc diameter below the right macula (Fig. 1). It was noted then that fixation in the right eye was poor and the vision only $6 / 60$. The left eye was occluded and the vision in the right eye improved to $6 / 6$ where it has remained for 2 years. The vision in the left eye was $6 / 5$.

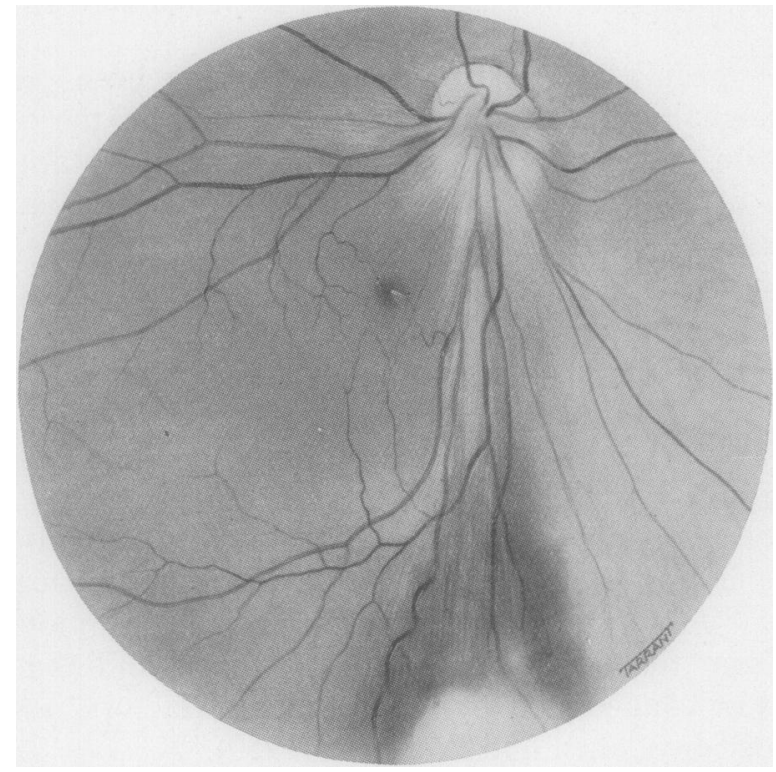

FIG. 1.-Fundus painting of right eye to show fibrous band causing downward displacement of macula.

The child is now aged 5 years and, although he appears to have a marked left hypertropia, is in fact fully binocular with an actual right hypertropia of $3 \triangle$ subjectively on the synoptophore (Fig. 2).

On the cover test, the depressed right eye becomes slightly more depressed when the left eye is covered.

The angle alpha in the right eye measured on the perimeter shows that the visual axis is elevated by $20^{\circ}$ from the optical axis, through the downward shift of the right macula.

It is thought remarkable that the vision in the affected eye should have responded so well to left occlusion and that binocular vision should have been attained in spite of the gross pathological lesion present. 


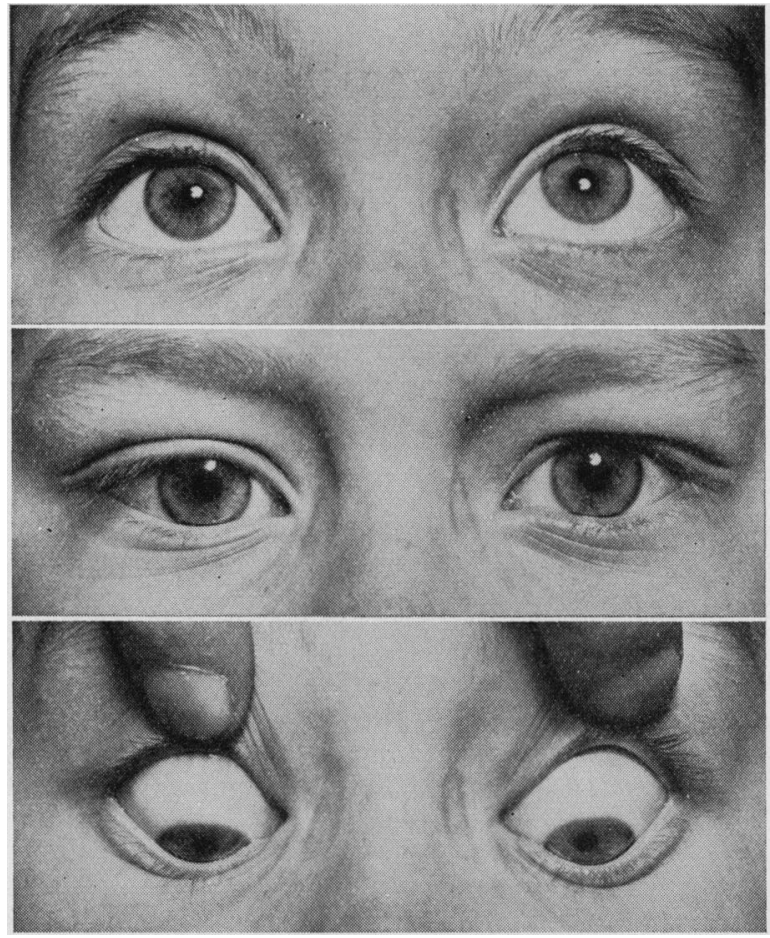

Fig. 2.-Photographs to show apparent depression of right eye through ectopia of right macula.

\section{Summary}

A case of vertical displacement of the macula by a post-inflammatory fibrous band in which full binocular vision was retained is described, and a brief review is given of the other possible aetiological factors which might cause ectopia of the macula.

My thanks are due to Mr. S. J. H. Miller for permission to publish this case and to the Medical Illustration Department of the Institute of Ophthalmology for the photographs and fundus painting.

\section{REFERENCES}

Beselin, O. (1924). Klin. Mbl. Augenheilk., 73, 691.

Bernhard, P. (1898). Arch. Augenheilk., 37, 51.

Bielschowsky, A. (1930). Klin. Mbl. Augenheilk., 84, 755.

BLAXTER, P. L. (1951). Trans. ophthal. Soc. U.K., 71, 231.

Cohen, I. J., and Weisberg, H. K. (1950). Arch. Ophthal. (Chicago), 44, 419.

FRIEDMAN, B. (1942). Ibid., 28, 444.

KRÜGER, A. (1913). Z. Augenheilk., 30, 21.

LANGE, O. (1900). v. Graefes Arch. Ophthal., 51, 342.

ManN, I. (1937). "Developmental Abnormalities of the Eye”. p. 157. University Press, Cambridge.

Pflüger, E. (1885). Arch. Augenheilk., 14, 1.

SteIn, R. (1931). Klin. Mbl. Augenheilk., 86, 188.

Triebenstein, O. (1919). I Ibid., 62, 442. 